\title{
CLEANING UP THE GREAT WEN: PUBLIC HEALTH IN EIGHTEENTH-CENTURY LONDON
}

\author{
Roy Porter
}

We know all too little about how the mortality and morbidity patterns of eighteenth-century London relate to the activities of the capital's doctors and of those who campaigned for better public health, and this essay pretends to make few inroads into the problem. ${ }^{1}$ In fact, we can hardly expect to have a sound basis upon which to build our explanations and interpretations, until far more research has been completed, analysing, parish by parish, such matters as population shifts, migration, and family structure. The aim of this discussion, rather, is to serve as a reminder that we need not unduly disadvantage ourselves in our attempts to understand the health of London by addressing these problems from misleading perspectives and with false expectations. In particular, if we take our norms for public health from the High Victorian age - as has all too often been done-we instantly turn what the Georgians actually did to improve the health of their metropolis into a self-defeating mystery.

\footnotetext{
I wander thro' each dirty street,

Near where the dirty Thames does flow,

And mark in every face I meet

Marks of weakness, marks of woe.
}

It was not just Blake who found Georgian London hell. Defoe had dubbed it "the monstrous city", Josiah Tucker found it "a kind of monster", "no better than a wen"; and William Cobbett, of course, damning all the nation's towns as "wens", anathematized the capital as the "great wen". This diagnosis of London as diseased, parasitic, and contagious, echoed down the century, with its connotations of sterility and death. ${ }^{2}$ For London tainted all it touched, sucking in the healthy from the

Roy Porter, PhD, Wellcome Institute for the History of Medicine, 183 Euston Road, London NW1 2BN.

\footnotetext{
${ }^{1}$ Combined demographic and social analysis of early modern London is now enlarging our understanding. See, for instance, S. Rappaport, Social structure and mobility in sixteenth-century London, Cambridge University Press, 1989; and John Walter and Roger Schofield, 'Famine, disease and crisis mortality in early modern society', in their Famine, disease and the social order in early modern society, Cambridge University Press, 1989, 1-74.

2 For Blake's 'London' see G. Keynes (ed.), Blake, Complete writings, Oxford University Press, 1972, 216. For men of letters' images of London in the eighteenth century see R. B. Schwartz, Daily' life in Johnson's London, Madison and London, University of Wisconsin Press, 1983; M. Byrd, London transformed, New Haven and London, Yale University Press, 1978; A. J. Weitzman, 'Eighteenth century London: urban
} 
countryside, and - as the Bills of Mortality proved-devouring far more than it bred. As Smollett's Matt Bramble complained: "the Capital is become an overgrown monster which, like a dropsical head, will in time leave the body and extremities without nourishment and support." 3 Within the civic humanist critique of depopulating luxury, which so haunted the Georgians, London seemed chief culprit in what the medical demographer, Thomas Short, called the "Waste of Mankind". 4

In the Augustan imagination, London served as an exemplar of iniquity. It was the headquarters of political gerrymandering and courtly decadence; its Grub Street was the high temple of Dulness; its Exchange spewed forth absurdities such as South Sea Bubbles; it was the poisoned spring of fashion and vice, the nursery of crime, riot, and all the other deformities and enormities lacerated in Samuel Johnson's Juvenalian satire, London. ${ }^{5}$ And not least, London was the hotbed of sickness. In his Journal of the plague year, Defoe reminded the Georgians that the great plague of 1665 had primarily decimated London more than elsewhere. ${ }^{6}$ But they could see with their own eyes the festering rookeries of St Giles (the cant-word "slum" was coined in Regency times to describe them) and sniff the stench of London's cloacina, the Fleet Ditch (that "King of Dykes", as Pope put it). ${ }^{7}$ Assailed by these images of London as slum and sewer, Georgians would be left in little doubt that when (in Cowper's contrast) "God made the country, and man made the town", it was the Divine Maker who was the true craftsman. ${ }^{8}$ And for some, the only consolation was that the megalopolitan Moloch could not endure, but would be laid low in some apocalyptic fury as foretold by the radical Richard Phillips in 1813: ${ }^{9}$

London will increase,... [but] the houses will become too numerous for the inhabitants, and certain districts will be occupied by beggary and vice, or become depopulated. This disease will spread like an atrophy in the human body, and ruin will follow ruin, till the entire city is disgusting to the remnant of the inhabitants; at length the whole becomes a heap of ruins: Such have been the causes of decay of all overgrown cities. Ninevah, Babylon, Antioch, and Thebes are become heaps of

\footnotetext{
paradise or fallen city?', J. Hist. Ideas, 1975, 36: 469-80. J. C. Lettsom called London “a painted sepulchre" in The improvement of medicine in London, London, Phillips, 1775.

${ }^{3}$ Quoted in Byrd, op. cit., note 2 above, 89.

4 T. Short, A comparative history of the increase and decrease of mankind in England and several countries abroad, London, Nicoll \& Etherington, 1767, 20.

${ }^{5}$ See P. Rogers, Grub Street: studies in a subculture, London, Methuen, 1980; J. E. Riehl, 'Fogs and the plague in The Dunciad: Arbuthnot's medical influence', CEA 44 (March, 1982): 5-10. Or, as a tirade, Hell upon earth, London, Roberts, 1729, put it:

London is a

great, wicked, unweildy [sic] overgrown Town, one continued hurry of Vice and Pleasure; where nothing dwells but Absurdities, Abuses, Accidents, Accusations, Admirations, Adventures, Adversities, Advertisements, Adulteries, Affidavits, Affectations, Affirmations, Afflictions, Affronts, Aggravations, Agitations, Agonies, Airs, Alarms, Ailments, Allurements, Alterations, Ambitions, Amours, Amphitheatres, Anathemas, Animosities, Anxieties, Appointments, Apprehensions, Assemblies, Assessments, Assurances, Assignations, Attainders, Audacities, Aversions, \&c.

${ }^{6} \mathrm{D}$. Defoe, A journal of the plague year, London, E. Nutt et al., 1722.

${ }^{7}$ P. Howard, London's river, London, Hamilton, 1975.

${ }^{8}$ For the mythology underlying this see R. Williams, The country and the city, London, Chatto \& Windus, 1973.

${ }^{9}$ B. I. Coleman, The idea of the city in nineteenth-century Britain, London, Routledge \& Kegan Paul, 1973, p. 39.
} 


\section{Public health in eighteenth-century London}

ruins. Rome, Delphi, and Alexandria, are partaking the same inevitable fate; and London must some time, from similar causes, succumb under the destiny of every thing human.

Easily Europe's biggest city, London was indeed notorious for its crush of humanity. The dreams of Wren and Hooke to redesign the City after the Great Fire on a noble ground plan had been lost (in Reddaway's words, London was restored, not replanned), ${ }^{10}$ and the urban jungle closed in. Open spaces and gardens were overrun by new houses, huts, and hovels making up De Quincey's fearful "Sphinx's riddle of streets"; the rookeries of courts and blind alleys shut out light and air and thus became the breeding-grounds of flyblown noisomeness and disease. ${ }^{11}$

The submerged classes crammed sardine-like into the slums of Whitechapel, Clerkenwell, and St Giles. Too poor to heed the rules of health, it was they who fell victims-in-chief to the Gin Craze, raging from the 1720s, which the contemporary demographer, Dr Thomas Short, reckoned responsible for some 12,000 deaths and for a shortfall of perhaps 40,000 births. ${ }^{12}$ And Londoners' health was constantly threatened by lax public hygiene and sewage disposal. The Thames still served both as the chief source of domestic water and as the main outlet for personal and industrial waste. Human ordure piled up around houses in stinking cesspools, often overflowing, infrequently emptied, sometimes leaking into wells, pipes and cellars. Excreta were also dumped into street drains and open sewers, which, lacking running water, stagnated and festered. The outcome was that London fell repeatedly victim to fever epidemics, especially bouts of dysentery, hospital or jail fever (typhus), as in the notorious Old Bailey outbreak in 1750 (the "Black Sessions"), which massacred some forty criminals, lawyers, judges and city officials alike, including the Lord Mayor.

The dangers of dirt were compounded by political inertia. Parliament left London's salubrity to the City; and the City passed the buck to parishes, which were mesmerized by the Poor Law philosophy of individual personal entitlements to relief, and coped with destitution, disease, and dying as well as the statute-book, the tight fists of

\footnotetext{
${ }^{10}$ T. F. Reddaway, The rebuilding of London after the Great Fire, London, Cape, 1940.
}

${ }^{11}$ A. Wohl, The eternal slum: housing and social policy in Victorian London, London, Edward Arnold, 1977 ; T. Beames, The rookeries of London, London, Bosworth, 1850; repr. London, F. Cass, 1970. See also P. J. Corfield, The impact of English towns, 1700-1800, Oxford University Press, 1982, ch. 5, 'The capital city'.

${ }^{12}$ Short, op. cit., note 4 above, 21: "Another fatal Engine for the Waste and Destruction of the Strength, Health, Intellects, Morality, and Religion of the Populace, both in City and Country, was the preparing and Consumption of incredible Quantities of Spiritous Liquors, a Poison producing Madness, Wickedness, Diseases, and Death, (as tho' other Liquors had been insufficient). This Engine began to diffuse it's pernicious Effects in 1724, at the very Time when the City began to be more fruitful and healthy that it had been since the Restoration. How powerfully this Poison wrought, let us now see: From 1704 to 24 , were born, 336,514; buried, 474,125. Let us allow fourteen Years for this dire Bane to spread, operate, and become epidemic; then from 1738 to 1758 , were born, 296,831; buried, 486,171. Here we have two shocking Effects of this bewitching Liquor: First, Here is a greater Barrenness, a Decrease or Want of 40,000 of ordinary Births, which the last Vicennary produced, instead of an Increase, as we had in other late Vicennaries. Secondly, An Increase of 12,000 Buryings, tho' there was so great a Defect of Births. This increased Mortality fell chiefly on Adults, which adds greatly to the Loss, as they were the most useful. Since this was the Case in one City, how fatal it must be over the whole Island? How was it possible then for the like Proportion of Children to die, since they were neither begotten nor born? This is a clear Arithmetical Demonstration of the cursed Effects of this stygian Poison. This plain Evidence is enough for the Legislature to suppress it's Use, by laying Duty upon Duty on Spirits". Cf. M. D. George, London life in the eighteenth century, Harmondsworth, Penguin, 1966, $41 \mathrm{f}$. 
rate-payers, and the myopia of amateur overseers would allow. But this meant there was no central concerted action to right the evils created by rapacious landlords, livestock markets, and slaughter-houses, fetid drains and sewers, industrial smoke and pollution. It was not in the eighteenth century that tumbledown tenements were razed. No New Oxford Streets or Charing Cross Roads were bulldozed through the rookeries (the age's single major New Road-significantly called just that-the present Marylebone, Euston, and Pentonville Roads - then bypassed the town itself). It was not then that the Thames was embanked, or burial grounds regulated and moved out of the City. The eighteenth century saw no Metropolitan Commissioners, no Boards of Works, no Parliamentary Inquiries, no Blue Books, no Sanitary Reports, no Chadwick, no Snow, no Simon, no Peabody.

To note these absences is not automatically to be anachronistic. After all, it was that eminent Georgian, John Wesley, who had judged cleanliness next to Godliness; and for centuries mercantilism had reckoned it good statecraft to secure the health, as well as the wealth, of nations. ${ }^{13}$ In the late-Stuart age, William Petty and then John Bellers had called for more hospitals, a ring of pesthouses, and state-funded provision of practitioners for common people, all presided over by a Council of Health and a minister of state. ${ }^{14}$ And cosmopolitan Englishmen knew that Italian cities had possessed medical bureaucracies and statutory anti-plague public health regulations since the late Middle Ages, and that cameralist health schemes had been elaborated in Enlightenment Germany in the "medical police" ideals of Johann Peter Frank, Rahn, Mai, and others. ${ }^{15}$

By contrast, there are few signs even of the desire for comprehensive public health regulation in Hanoverian England. In 1796, that centralising Benthamite magistrate, Patrick Colquhoun, could write a 600-page treatise on the police of London without so much as broaching the idea of sanitation or medical police. Indeed, the first book in English expressly on that topic-John Roberton's Medical police (1812)-is significantly a work of the nineteenth century, and written by a Scot for the Scots, who, with their civil law jurisprudence, were more open than the English to Cameralwissenschaft. And what is more revealing is that Roberton's book in fact contains almost nothing that Frank would have recognized as a genuinely cameralwissenschaftliche medical police, for Roberton's agenda amounted to little more than platitudinous individualist hygiene advice (to be healthy, avoid vice, poverty, and squalor), within the time-honoured framework of the non-naturals.

${ }^{13}$ Cf. V. S. Smith, 'Cleanliness: the development of an idea and practice in Britain 1770-1850', London School of Economics, PhD diss., 1985.

${ }^{14}$ See G. Rosen, From medical police to social medicine, New York, Science History Publications, $1974 ;$ G. Clarke (ed.), John Bellers: his life, times and writings, London, Routledge \& Kegan Paul, 1987.

${ }^{15} \mathrm{R}$. Palmer, 'Physicians and the state in post-medieval Italy', in A. Russell (ed.), The town and state physician in Europe from the Middle Ages to the Enlightenment, Wolfenbüttel, Herzog August Bibliothek, 1981, 47-62; C. Cipolla, Public health and the medical profession in the Renaissance, Cambridge University Press, 1976; cf. Rosen, op. cit. note 14 above, 145, discussing Heberstreit's Lehrsätze der medicinischen Polizeywissenschaft (1791) which expounded "the science which teaches how to apply dietic and medical principles to the promotion, maintenance and restoration of the public health, [a science which embraced] procreation, maternal and child welfare, nutrition and food sanitation, housing, hygiene of clothing, recreation, occupation, accident prevention, control and prevention of epidemics, organization of the medical profession, provision of medical care, nursing of the sick, and enlightenment of the public in health matters". 


\section{Public health in eighteenth-century London}

Indeed, historians have traditionally agreed that there was no significant public health movement under the Georges. In Sir John Simon's classic statement, ${ }^{16}$

In 1830 , when William the Fourth began his reign, and equally in 1837 when the reign ended ...the statute book contained no general law of sanitary intention ... the central government had nothing to say in regard to the Public Health, and local authorities had but the most indefinite relation to it.

Simon's verdict is still often endorsed. For example, C. Fraser Brockington has stated that "at the turn of the nineteenth century little official machinery of public health was known to exist in Britain". ${ }^{17}$ Public health is assumed instead to have been a nineteenth-century-indeed a Victorian-achievement, spurred by Evangelicalism, Benthamism, the horrors of industrialization, and the unarguability of cholera (according to The Times, "the best of all sanitary reformers"). ${ }^{18}$ The implication is that the grandfathers of the Victorians had no passion for sanitation, being, perhaps, as tolerant of filth, as, allegedly, they were inured to pain. Admittedly, certain stirrings and precursors are acknowledged, predictably amongst the heroes of historians of reform, namely, provincials and religious Dissenters-Currie in Liverpool, Haygarth in Chester, the promoters of the Board of Health and Fever Hospital in Manchester, in particular John Ferriar. But-as E. P. Hennock has insisted-such pioneers should not be confused with the Chadwickian movement, for they achieved little and certainly nothing in London, where the medical colleges slumbered, mindless of public obligations and lulled by the excuse of "out of sight, out of mind". ${ }^{19}$ For in an urban geography where patricians and plebeians kept increasingly separate quarters, the élite might little know how the other half lived (to complete his education, Sam Johnson urged Boswell to "explore Wapping").

There is a truth in all this. But it is only a partial truth, and dangers lurk in tracing the "people's health" question through Chadwickian eyes. London, though Babylon to some, to others was paradise. The Johnson who wrote London also, of course, judged the man who was tired of London to be tired of life. And many found it a picture of beauty and health-“Earth has not anything to show more fair": high praise indeed from a lover of Nature in the wild, and evoking not Hogarth's sink of sin but Canaletto's majestic townscapes (and even Hogarth depicted healthy Beer Street as well as hellish Gin Lane). Listen to foreigners' reactions. As well as rhapsodizing over London's wealth, shops, ample food supply and nonpareil street lighting, many praised the convenience of its well-paved streets, flagged with Aberdeen granite, and found the English second only to the Dutch in domestic cleanliness and in water consumption. London's facilities for the sick and unfortunate impressed many. "London", apostrophized Sophie von la Roche in the $1780 \mathrm{~s}^{.20}$

\footnotetext{
${ }^{16}$ Sir J. Simon, English sanitary institutions, 2nd ed., London, Cassell, 1897, 166.

${ }^{17}$ C. Fraser Brockington, Public health in the nineteenth century, Edinburgh and London, Churchill, 1965, 1; cf. A. Newsholme, The evolution of preventive medicine, London, Baillière, 1927.

${ }_{18}$ Quoted in F. H. W. Sheppard, Local government in St Marylebone 1688-1835, London, Athlone, 1958, 270.

${ }^{19}$ B. Keith-Lucas, 'Some influences affecting the development of sanitary legislation in England', Econ. Hist. Rev. 2nd ser., 1953-4, 6: 290-6; E. P. Hennock, 'Urban sanitary reform a generation before Chadwick?', ibid., 1957-8, 10: 113-19.

${ }^{20}$ C. Williams (ed.), Sophie in London 1786, London, Cape, 1933, 177.
} 
your foundling home, the education of your orphans, the philanthropy which tends your poor women in labour and your wretched lunatics, are distinctive traits of your charity, wisdom and great-heartedness. Faults you must possess while human kind inhabits you-imperfection is our common lot-but how much good, what measure of perfection is yours.

Favourable verdicts indeed, jestingly captured in Horace Walpole's mock medical prescription: "Were I a physician, I would prescribe nothing but $R$ : ccclxv drachm. Londin'. 21

After all, Georgian London was still small. Even in 1800 you could stroll right across it from north to south comfortably within an hour. Much of the housing stock was in good condition because the fire of 1666 had destroyed the bulk of the medieval and Tudor City, forcing the building of 10,000 new dwellings. And because of the strictness of the London Building Act (1667)'s regulations concerning materials, design, and standards, these houses were not jerry-built. ${ }^{22}$ Constructed of brick and stone, and with tiled, not thatched roofs, and free of gables and overhangs, they were vermin-proof as well as fireproof. Looking at their rebuilt City, late-Stuart citizens swelled with London pride. As John Woodward, Professor of Physick at Gresham College, noted, the Fire

disastrous though it might be to the then inhabitants, had prov'd infinitely beneficial to their Posterity; conducing vastly to the Improvement and Increase, as well of the Riches and Opulency, as of the Splendor of this City. Then ... by means of the Inlargements of the Streets; of the great Plenty of Good Water, convey'd to all Parts; of the common Sewers, and other like Contrivances, such Provision is made for a free Access and Passage of the Air, for Sweetness, for cleanness, and for Salubrity, that it is not only the finest, but the most healthy City in the World. ${ }^{23}$

Furthermore, the eighteenth century was not one of perilous population explosion for the capital. Statistics make the point. Stuart London more than tripled in size, from about 200,000 inhabitants in 1600 to 674,000 in 1700 . During the eighteenth century, however, London grew by less than a third, rising to some 958,000 souls; but then it doubled-to $1,948,000$ - within the next forty years. The nightmare ghettos of Mayhew's day, such as Bethnal Green, were still reasonably rural at the close of the eighteenth century.

By contrast, the new geography of the Georgian capital comprised first-rate housing developments that neither degenerated into slums, nor added to industrial pollution. Grids of gracious, spacious, leafy squares spread north and west, across Bloomsbury, Soho, and Marylebone, through the private development of great aristocratic estates like the Bedfords'. Tight landowner control of ground plans, housing density, and building standards, and the prohibition of warrens of lowerclass tenements, workshops, and markets, meant that these paradigms of planning

${ }^{21}$ G. E. Mingay, Georgian London, London, Batsford, 1975, 12.

22 Reddaway, op. cit., note 10 above, 300; M. C. Buer, Health, wealth and population in the early days of the Industrial Revolution, London, Routledge, 1926, 319.

${ }^{23}$ Reddaway, op. cit., note 10 above, 300 . 
realized the genteel dream of the garden city, rus in urbe, as outlined in John Evelyn's Fumifugium. ${ }^{24}$

Furthermore, the colonization of the West End as London's ritzy living quarterabetted by the sprouting of such dormitory suburbs as Hampstead-had the beneficial side effect of relaxing housing pressure within the old City. The custom of living where one worked declined, and those who could afford it, escaped beyond the walls. The result was that fewer people lived within the City in 1800 than a century earlier; and, as Dr Gilbert Blane suggested, "The thinning of the population since that time must have had the most beneficial effects upon health". 25

Moreover, merely because the Georgian age had no Chadwick, no Bazalgette, no Metropolitan Board of Commissioners, it is too easy to ignore what was done to make the area of the Bills of Mortality more salubrious. Building standards were regulated by law from the 1667 London Building Act through to the comprehensive legislation of 1774 and beyond. ${ }^{26}$ The Corporation spent some $£ 80,000$ after the Fire in canalizing the Fleet River, which from 1763 was in any case enclosed below Holborn, reducing noisomeness from ordure and effluent.

Admittedly, neither Parliament nor the City Corporation took initiatives to clean up the capital. Yet, perhaps exemplifying what Roach has termed the English habit of "individual initiative and corporate passivity", 27 strides were made by groups of influential vestrymen and other citizens in metropolitan parishes. Traditionally, responsibility for the cleanliness and good lighting of London streets had rested with each individual householder. This was dramatically changed by a series of private acts of Parliament, in particular the 1762 Westminster Improvement Act and the 1766 City Improvement Act. These directed vestries to appoint commissioners empowered to raise a household rate and to treat with contractors for street management. Commissioners entered into contracts for repaving the streets, replacing old cobbles with flagstones, and the dangerous ditches in the middle of roadways with properly constructed kerbs and gutters; for new street lighting, to deter street crime; for regular scavenging (streets were to be raked and swept, and garbage collected, on a regular basis); and for the removal of such nuisances as dangerous street signs and rubbish tips. As always, householders made a great to-do against the exorbitancy of the rates (about $4 d$ in the pound), but there can be little doubt (as Francis Sheppard has shown in his study of Marylebone) that where vestrymen and commissioners were efficient, the result transformed the face of London's streets. ${ }^{28}$ Steps were also taken to enlarge

\footnotetext{
${ }^{24}$ For a contemporary view see James Stuart, Critical observations on the buildings and improvements of London, London, J. Dodsley, 1771. See also G. Rudé, Hanoverian London 1714-1808, London, Secker \& Warburg, 1971; Sir John Summerson, Georgian London, 1945; rev. ed., Harmondsworth, Penguin, 1978 ; D. Olsen, Town planning in London, New Haven and London, Yale University Press, 1982; Hugh Phillips, Mid-Georgian London: a topographical and social survey of Central and Western London about 1750, London, Collins, 1964; idem., The Thames about 1750, London, Collins, 1951.

${ }^{25} \mathrm{G}$. Blane, Observations on the comparative prevalence, mortality and treatment of different diseases, London, Woodfall, 1813. The City's population may have dropped from about 200,000 in 1700 to about 125,000 in 1830. See: Great Britain, House of Commons, Comparative account of the population in Great Britain in the years $1801,1811,1821$, and $1831 \ldots$ London, 1831.

${ }^{26}$ Buer, op. cit., note 22 above, 79.

27 J. Roach, Social reform in England, 1780-1880, London, Batsford, 1978, 83.

${ }^{28}$ Sheppard, op. cit., note 18 above. See for example J. Spranger, A proposal or plan for an Act of Parliament for the better paving, lighting, cleansing the streets, lanes, courts, alleys, and other open passages,
} 
London's water supply. Between 1669 and 1806 nine new water companies were floated, which drew water from the Thames; for drinking, the quality may have been dubious, but the fuller supply was useful for cleansing and flushing.

Contemporaries were impressed. Visiting London in 1785 , the chauvinistic Brummie, William Hutton, waxed lyrical: ${ }^{29}$

The stranger will be astonished at the improvements which have been introduced during the last 35 years and how money could be procured to complete them. He will find every street and passage in the whole city, and its environs, has been paved in one regular and convenient stile; [as] the people of Birmingham ... must observe the conveniency arising from open streets, the centers of which are regularly paved and the sides, from one foot to sixteen, according to the width of the street, laid with flat stones, for the benefit of the passenger, it is surprizing they do not, at a humble distance, wish to imitate the Metropolis.

Medical opinion was similarly proud. Dr Thomas Short, a doughty critic of "corruption" with an eagle eye for feculence, remarked glowingly of the metropolis in $1767:^{30}$

Many of its Streets have been widened, made straight, raised, paved with easy Descents to carry off the Water; besides Wells in most public Yards; and Pipes for conveying Plenty of fresh Water to keep them clean and sweet.

And, he concluded, referring to the Bills of Mortality:

It also appears from the Tables and Ages, that virtuous temperate People, of most Constitutions ... often live as long in London as their Neighbours in their own native Soil.

Then let us turn from street management to public health. Historians long ago concluded that the eighteenth century lacked a public health movement; Georgian medical practitioners (it is presumed) were not interested in sanitation, preventive medicine, or "social medicine". The clinical gaze-it is assumed-focused on

and for removing of nuisances as well within the several parishes of the City and Liberty of Westminster as of St Mary le Bone, St Giles in the Fields, St George the Martyr, etc., London, for S. Baker, 1754; and A letter to Mr. John Spranger, London, 1754, which discusses the need for better street furniture, side-gutters, scavengers, rakers, etc., while voicing the worry that we may become "police mad".

${ }^{29}$ L. Jewitt (ed.), The Life of William Hutton ..., London, Warne, [n.d.], 69, 154

${ }^{30}$ Short, op. cit. note 4 above. As a parallel, note that Dr William Black reported in his Observations medical and political, London, Johnson, 1781, 135-6, that "the London inhabitants are now much more widely dispersed ... formerly the city was close confined and unhealthy... London streets are now widened, the inhabitants live less crowded together, the houses stand upon double or treble the ground which they formerly occupied, ventilation is freer, the city is more plentifully supplied with water and fuel, both extremely necessary in preserving health ... the streets are better paved ... sewers and drains are made to carry off moisture and corruption...". T. Bateman wrote in his Reports on the diseases of London, London, Longman, 1819, 19-20: "Fleet ditch was then first covered in: the streets were paved with squared large stones ... the sewers and drains were improved; openings were made in the incommodious parts of the streets; and cleanliness still farther promoted by the more active employment of scavengers, the increased supply of water, etc.; which system has been pursued and is still continued to the great ornament of the town, as well as the substantial benefit of its inhabitants." 


\section{Public health in eighteenth-century London}

individual patients rather than on the body politic, valuing cure rather than prevention, therapeutics not engineering. Doctors were heirs to humoralism, and subscribed still to models of disease as the result of individual imbalance. So far as they were concerned with prophylaxis at all, they concentrated upon personal regimes of moderation and self-management, with an eye to the non-naturals. ${ }^{31}$

There is some truth in this characterization, and it says something that the greatest Georgian campaigners against abuses and squalor-for example, Jonas Hanway and John Howard-were not medical men at all. Yet it would be quite wrong to infer that physicians were ignorant of, or indifferent to, the links between personal well-being and environment. Abundant experience brought home the connections between disease and squalor. Take for instance, this clinical record from John Hunter: ${ }^{32}$

In the month of February I met with two examples of fever in the lodgings of some poor people whom I visited that resembled in their symptoms the distemper which is called the jail or hospital fever. It appeared singular that this disease should show itself after three months of cold weather. Being therefore desirous of learning the circumstances upon which this depended I neglected no opportunity of attending to similar cases. I soon found a sufficient number of them for the purpose of further information. It appeared that the fever began in all in the same way and originated from the same causes. A poor family, consisting of the husband, the wife, and one or more children, were lodged in a small apartment not exceeding twelve or fourteen feet in length, and as much in breadth. The support of them depended on the industry and daily labour of the husband, who with difficulty could earn enough to purchase food necessary for their existence, without being able to provide sufficient clothing or fuel against the inclemencies of the season. In order therefore to defend themselves against the cold of the winter, their small apartment was closely shut up, and the air excluded by every possible means. They did not remain long in this situation before the air became so vitiated as to affect their health and produce a fever in some one of the miserable family. The fever was not violent at first, but generally crept on gradually ... soon after the first, a second was seized with the fever, and in a few days more the whole family perhaps were attacked, one after another, with the same distemper. I have oftener than once seen four of a family ill at one time and sometimes all lying on the same bed.

Drawing on experiences like this, physicians probed the social geography of infection, as when Lettsom noted in 1773:

In the airy parts of this city and in large, open streets, fevers of a putrid tendency rarely arise ... In my practice I have attentively observed that at least forty-eight of fifty of these fevers have existed in narrow courts and alleys. ${ }^{33}$

Both medical inquiries and medical theory backed this emergent epidemiological vision based on experience. Investigations into fevers, recognized to be the most widespread and lethal diseases, were important. During the eighteenth century, fevers

${ }^{31}$ O. Temkin, 'An historical analysis of the concept of infection', in his The double face of Janus, Baltimore, MD, Johns Hopkins University Press, 1977, 456-70.

${ }^{32}$ Quoted in C. Creighton, A history of epidemics in Britain, vol. 2, Cambridge University Press, 1891-4,

138. This is not the famous John Hunter, brother of William.

${ }^{33}$ Quoted in ibid., 133-4. 
became prime targets of research, with Huxham investigating typhus, typhoid, and diphtheria; Mead, plague; Heberden, diphtheria and chicken-pox; Fothergill, epidemic sore throat; Haygarth, smallpox, typhus and rheumatic fever; Withering, scarlet fever and tuberculosis; and so forth. ${ }^{34}$ And these epidemics were recognized as striking hardest at the common people and being coterminous with foul habitations. Medical quantifications also helped advance an empirical epidemiology. From Fothergill and Bisset in mid-century to Willan and Bateman at the end, tabulations were prepared plotting fever outbreaks against the axis of meteorological conditions. And, as Ulrich Troehler has demonstrated, many physicians kept their own records of fever epidemics, cases and cures, or processed data from hospitals, dispensaries and the Bills of Mortality, to establish medical topographies. ${ }^{35}$

Such investigations were of course guided by theoretical expectations. The Hippocratic discourse on "Airs, Waters and Places" has presupposed a vital-if oblique-link between health and the natural and man-made environments ${ }^{36}$ For certain Georgian doctors this tradition entailed what seems the very English view that it was (as Bateman put it) the "vicissitudes of the weather" to which the "great mass of human malady . . . is referable". For others, however, it was the social milieu that counted, thus opening prospects of an interventionist social medicine. ${ }^{37}$

In the Victorian age, that Napoleon of sanitarians, Edwin Chadwick-a deflator of doctors, men, he thought, "without the skill to prevent"--wrote that what made the medical profession so supine about sanitary reform were their false dogmas as to the nature of epidemic infection. ${ }^{38}$ Doctors (he argued) saw fevers either as symptomatic of some internal imbalance of the individual metabolism, or as resulting from specific contagion (that is, direct person-to-person transfer of disease entities through "seeds", "animalcules" or whatever). For Chadwick, these "contagionist" doctrines were self-serving, and represented sloppy thinking. By contrast, he espoused what became known as "anti-contagionism". Epidemic diseases such as typhus, typhoid, and cholera were the effects of filth. Feculent conditions, stagnant pools, rotting animal and vegetable matter, garbage, ordure, and the stench of huddled humanity, especially the sick - all these gave off miasmas or effluvia which were themselves disease entities infecting those coming under their influence. For Chadwick, quite literally, "all smell is disease". ${ }^{39}$ His anti-contagionism was simple, as was his clarion call for prevention: a system of water flowing in abundance at pressure through the

\footnotetext{
${ }^{34}$ W. F. Bynum, 'Cullen and the study of fevers in Britain 1760-1820', in W. F. Bynum and V. Nutton (eds), Theories of fever from antiquity to the Enlightenment, Med. Hist., Supplement 1, London, Wellcome Institute, 1981, 135-148. For an example see T. Bateman, A succinct account of the contagious fever of this country exemplified in the epidemic now prevaling in London, London, Longman, 1818.

${ }^{35} \mathrm{U}$. Troehler, 'Quantification in British medicine and surgery, 1750-1830, with special reference to its introduction into therapeutics', London University, PhD diss., 1978; see for example Bateman, op. cit., note 30 above.

${ }^{36}$ L. J. Jordanova, 'Policing public health in France 1780-1815', in T. Ogawa (ed.), Public health, Tokyo, Tanaguchi Foundation, 1981, 12-32; G. Miller, 'Airs, waters and places in history', J. Hist. Med., 1962, 17: 129-40.

${ }^{37}$ Bateman, op. cit., note 30 above, ch.8.

38 J. M. Eyler, Victorian social medicine: the ideas and methods of William Farr, Baltimore and London, Johns Hopkins University Press, 1979; S. E. Finer, The life and times of Sir Edwin Chadwick, London, Methuen, 1952, 158.

${ }^{39}$ Eyler, op. cit., note 38 above, $100 \mathrm{f}$.
} 
metropolis, and carrying away waste through mains drainage, thus disposing of filth before it could turn pestilential. The key lay in engineering-"of which the medical men knew nothing". The ditherings of the doctors, by contrast, mystified the matter and failed to provide rationales for action. ${ }^{40}$

Yet Chadwick's indictment, that medical opinion was wedded to constitutionalist or contagionist dogmas, in such a way as to render public health action nugatory, is greatly misleading. Eighteenth-century medical thinking on the cause of epidemics and the nature of infection was many-faceted, subtle, and eclectic. There was no single party line, no simple polarization of debate. Investigators did not see the "aetiology of epidemics" issue as requiring a choice between blaming the individual or the environment (did the pig make the sty, or the sty make the pig?), or between the blanket acceptance or denial of specific contagion. ${ }^{41}$ Rather, the problem lay in discerning which diseases were specifically contagious or not-no doctor would deny, for example, that syphilis was contagious through direct sexual contact, and inoculation proved smallpox too was transmitted by a disease virus. ${ }^{42}$

Two features of eighteenth-century medical opinion, however, stand out. First, even without theoretical consensus, all acknowledged the Humean, constant conjunction between filthy environments and outbreaks of epidemic disease. Leading physicians and humanitarians tackling epidemics and the diseases of towns, ships, camps, garrisons, jails and hospitals-Mead, Howard, Hanway, Huxham, Haygarth, Blane, Lettsom, to name but a few-agreed that where there was filth, there would be the risk of an epidemic.

Second, precise theoretical leanings generally made little difference to agendas. The one major exception was the case of bubonic plague, where contagionism was habitually yoked to the demand for compulsory quarantine. Contagionists advocated these drastic measures because plague was deadly, uniquely virulent, and spread like wildfire. In the plague scare of 1720 , sparked by the Marseilles outbreak, the establishment medical view was formulated by Dr Richard Mead, who had been commissioned by the Secretary of State to pronounce on the matter. In his Short discourse concerning pestilential contagion, and the methods to be used to prevent it (1729) Mead plumped for the traditional package of contagion plus quarantine, measures opposed by those who denied the specific contagiousness of plague, who feared that quarantine-a "French measure"-would ruin British trade, and believed that plague was being exploited as a pretext for encroachments by the Walpolean "police state". 43

But with other fevers, all parties-specific and general contagionistsrecommended similar measures. They were not those characteristic of Chadwick's

\footnotetext{
${ }^{40}$ Finer, op. cit., note 38 above, 218 ; Eyler, op. cit., note 38 above.

${ }^{41}$ See for example S. Schaffer, 'Priestley's questions: a historiographical survey', Hist. Sci., 1984, 22: $151-83$, and the literature cited there.

${ }^{42}$ For this debate see E. Ackerknecht, 'Anticontagionism between 1821 and 1867', Bull. Hist. Med., 1948. 22: 562-93; M. Pelling, Cholera, fever and English medicine 1825-1865, London, Oxford University Press, 1978; R. Cooter, 'Anticontagionism and history's medical record', in P. Wright and A. Treacher (eds), The problem of medical knowledge, Edinburgh, Edinburgh University Press, 1982, 87-108.

${ }^{43}$ C. F. Mullett, 'The English plague scare of 1720-23', Osiris, 1936, 2: 484-516. See especially R. Mead, $A$ short discourse concerning pestilential contagion, and the methods to be used to prevent it, London, Buckley \& Smith, 1720.
} 
drain-brain optimism of the early-Victorian decades: remove filth, install a system of high-pressure water and a main drains network, and salubrity would reign. Nor, however, were they marked by environmental fatalism like that of the doctrinaire laissez-faire advocate, René Villermé, in Restoration Paris, who argued that epidemics stemmed not from environmental horrors but from malnutrition; malnutrition stemmed from poverty; and since poverty in turn resulted from the iron laws of political economy, or from personal fecklessness, there was little public health could do. ${ }^{44}$ Georgian doctors did not anticipate this therapeutic nihilism-and rightly, for Andrew Appleby has shown that epidemic crises in Georgian London did not coincide with seasons of dearth and thus malnutrition. ${ }^{45}$ Georgian doctors neither wrung their hands in despair, nor mounted political campaigns for transforming the urban environment by statute. Rather they acted to remove some of the sick from the sites of contagion, medicated others in situ, and instructed the people in habits of hygiene. ${ }^{46}$

To some degree, the general hospital movement was the means to the first end. During the eighteenth century the two medieval London hospitals were augmented by five new general hospitals and about eleven specialized hospitals-such as lying-in hospitals, the Foundling Hospital, lock hospitals, etc.-all catering for the poor, and offering at least a spell of bed-rest and substantial diet-and, it seems, reasonably salubrious conditions-for some 20-30,000 patients a year by the end of the century. ${ }^{47}$ General hospitals, of course, were not designed to cope with the great killer, fever epidemics, since their admissions policies excluded contagious diseases. But two later developments aimed to cater to that need.

\footnotetext{
44 W. Coleman, Death is a social disease, Madison and London, University of Wisconsin Press, 1982.

${ }^{45}$ A. Appleby, 'Nutrition and disease: the case of London, 1550-1750', J. interdis. Hist., 1975, 6: 1-22. Appleby's findings are challenged and modified somewhat by P. R. Galloway, 'Annual variations in death by age, deaths by cause, prices and weather in London, 1670-1830', Population Studies, 1985, 39: 487-505.

${ }^{46}$ Some also urged urban improvement. Cf. C. Stanger, Remarks on the necessity and means of suppressing contagious fever in the Metropolis, London, W. Phillips, etc., 1802, 26-9: "Lanes and alleys may be widened, courts opened, yards and areas enlarged. The number of stories and rooms in the houses of the lower classes may be limited, and the latter augmented in size. The proportion, number, position, size, as well as the construction, of doors, windows, and chimnies, may also be regulated. Much security might be obtained by restricting the number of families, in each house, and of individuals in each apartment. The inhabiting of cellars, in which a considerable proportion of the lower classes dwell, immersed in darkness and damp, and in impure and stagnant air ought, more particularly, to be regulated, if not prohibited." Stanger admitted that these reforms would indeed require legislation and police: "The means, however, of civil police, most effectual for remedying the evil of contagion, by destroying its source, cannot be carried into effect, without overcoming considerable obstacles. Space, pure air, and cleanliness, sufficient for health, are wanting to the most numerous classes of mankind. The preventive measures proposed, of improving the situation and construction of houses, of limiting the number of inhabitants, of supplying the means and enforcing the practice of cleanliness, cannot be effected without interfering with the disposition of private property, and with domestic economy. Considerable expence must also be necessarily incurred. These radical means for preventing the generation of contagion cannot therefore be completely attained, without the aid of the legislature. Much, however, may be accomplished by the exertions of magistrates, and parish officers, under the existing laws, and, by the well directed efforts of enlightened philanthropists." In the short term, however, nothing came of these suggestions.

${ }^{47}$ See George, op. cit., note 12 above, 48; J. Woodward, To do the sick no harm: a study of the British voluntary hospital system to 1875, London and Boston, Routledge \& Kegan Paul, 1974; David Owen, English philanthropy 1660-1900, Cambridge, Mass., Harvard University Press, 1965; B. Rodgers, Cloak of charity, London, Methuen, 1949.
} 
First, the dispensary. Stemming from the founding of the London Dispensary in 1773 at the prompting of John Coakley Lettsom, the dispensary movement became, as Irvine Loudon has shown, a living fountain of medical services to the London poor. By 1800 some sixteen London dispensaries were handling up to 50,000 cases a year. While most patients obtained little more than a rapid consultation and free medicine, the dispensary movement also aimed to provide domiciliary visits by physicians to the homes of the sick poor. Lettsom himself claimed in 1775, "During the last three years, I have attended nearly six thousand poor persons; into many of whose habitations I have entered, and been conversant with their sufferings". Contemporary sources suggest that anything up to a third of the 50,000 encounters involved home visits that gave the medical profession practical first-hand experience of "darkest England". 48

Arising out of the dispensary movement came the first London fever hospital (euphemistically known as the House of Recovery), founded in 1801, to remove the fever victim from his contagious milieu, both to aid his own recovery and to safeguard those at risk. 49

In tandem with dispensaries and hospitals-and in addition to the great debate about the salubrity of hospitals, jails and other public buildings-were attempts to prevent epidemics, both by smallpox inoculation, and by health education. Through hospitals, dispensaries and pamphleteering, Londoners were exposed to a blizzard of advice that advocated fresh air, body washing, clean linen, and clean living. ${ }^{50}$ For, as Dr Christopher Stanger put it, "next to renewing the air of habitations, personal domestic cleanliness is most efficacious in dispersing the seeds of contagion". 51

Contemporaries concluded that improvement worked. Take cleanliness, for example. "In the space of a very few years", claimed Lettsom:

I have observed a total revolution in the conduct of the common people respecting their diseased friends. They have learned that most diseases are mitigated by a free admission of air, by cleanliness and by promoting instead of restraining the indulgence and care of the sick. ${ }^{52}$

48 I. S. L. Loudon, 'The origins and growth of the dispensary movement in England', Bull. Hist. Med., 1981, 55: 322-42. Lettsom, op. cit., note 2 above, 25.

${ }^{49}$ W. F. Bynum, 'Hospital, disease and community: the London Fever Hospital, 1801-1850', in C. E. Rosenberg (ed.), Healing and history: essays for George Rosen, New York, Science History Publications; and Folkestone, Kent, Dawson, 1979, 97-115.

${ }^{50}$ Smith, op. cit., note 13 above; cf. Roy Porter, 'Sex and the singular man: the seminal ideas of James Graham', Studies on Voltaire and the Eighteenth Century, 1984, 228: 1-24.

${ }^{51}$ Stanger, op. cit., note 46 above, 27 . It was important for Stanger-who was physician to the Fever Hospital-to stress that the way forward lay in studying facts not theory (p.7): "In populous towns, especially in this immense metropolis, the poor are exposed to a variety of wretchedness little known, except to those, who are obliged to witness their wants and sufferings. Continued Labour exhausts their strength, whilst scanty and unwholesome food affords insufficient support. Air and light are, in a great measure, excluded from their habitations, whilst damp and cold frequently predominate. Human effluvia and exhalations from putrefying vegetable and animal substances, within and about their sordid dwellings, are constantly accumulating; and the atmosphere of one polluted cell is but exchanged, for that of another."

52 Quoted in George, op. cit., note 12 above, 51. Cf. Bateman, op. cit., note 30 above, 19-20: "the sewers and drains were improved; openings were made in the incommodious parts of the streets; and cleanliness still farther promoted by the more active employment of scavengers, the increased supply of water, \&c.: which system has been pursued, and is still continued, to the great ornament of the town, as well as to the 
Gilbert Blane similarly believed that the living conditions of the poor had improved as a result of the greater use of cotton clothing, soap, water, and cheap fuel. And, judged Dr Marshạll in 1817,

If any causes could have contributed to the immunity we enjoy from the plague and bad fevers they are to be found in the greater cleanliness and less crowded state of the inhabitants, with the widening of the streets, and the better and more general construction of common sewers and drains, to which may be added the profusion of water now distributed through the metropolis. ${ }^{53}$

These personal judgements were borne out by vital statistics. For when contemporaries examined the Bills of Mortality, they saw a remarkable turnabout towards the close of the century. ${ }^{54}$ Till then, London-like all the world's conurbations - had been a death trap. Burials had always far outstripped baptisms, a sure sign that London lured in victims from outside and then prematurely ended their days. And in the first half of the eighteenth century, aggregate London baptisms had actually been falling and burials rising. But these trends were now being reversed. By the close of the century, baptisms had risen, and the burials total was, for the first time, dropping. These conclusions, far from merely indicating statistical naïveté, are confirmed by today's demographic historians. Wrigley and Schofield's table says it all: 55

BAPTISMS AND BURIALS IN LONDON BY QUARTER CENTURY

\begin{tabular}{lll}
\hline Period & Baptisms & Burials \\
\hline $1700-24$ & 462,116 & 593,835 \\
$1725-49$ & 475,151 & 679,922 \\
$1750-74$ & 459,978 & 612,046 \\
$1775-99$ & 555,388 & 601,572 \\
$1800-24$ & 687,136 & 598,718 \\
\hline
\end{tabular}

Whereas between 1725 and 1750 London had occasioned about a 200,000 net loss of population to the nation, by $1800-25$ it was contributing a net gain of some 88,000 .

substantial benefit of its inhabitants. The construction of houses, too, which have been astonishingly multiplied since that period, being calculated in every way for the promotion of internal ventilation and cleanliness, and the general attention at present paid to these circumstances in domestic economy, add to the causes of the great salubrity of the metropolis during several years past."

${ }^{53}$ Quoted in George, op. cit., note 12 above, 59.

$54 \mathrm{Cf}$. the explanation offered by William Heberden, Jr: "Anyone who will be at the pains to compare the conditions of London and all the great towns of England during the seventeenth century with their actual state and note the corresponding changes which have taken place in diseases, can hardly fail to consider cleanliness and ventilation as the principal agents in producing this reform. And to this may be added ... the increased use of a variety of vegetables among the ranks of our people [and] the ... spirit of improvement which has constructed our sewers and widened our streets and removed the nuisances with which they abounded, and dispersed the inhabitants over a wider surface and taught them to love airy apartments and frequent changes of linen." Observations on the increase and decrease of different diseases, London, Lackington, 1801, 30 .

${ }^{55}$ E. A. Wrigley and R. S. Schofield, The population history of England 1541-1871, London, Edward Arnold, 1981, 167. 
Thus, thanks to a falling death rate, partly attributable to better urban conditions and medical initiatives, London had ceased to be a sink of humanity and had become a spring. These improvements in Londoners' health did not last, of course. The perhaps superficial, yet effective, urban improvements and medical advances of the eighteenth century were soon swamped by the capital's unparalleled early nineteenthcentury explosion-by 1840 a million new inhabitants, largely working-class, were occupying new slum areas that lacked any public services even as they began to accommodate the great influx of polluting heavy industry and its accompanying canals, chemicals, gasworks, docks, and railyards.

Because it had to cope with problems of a new order of magnitude, the public health transformation from Chadwick to Simon and Bazalgette deserves to be regarded as qualitatively different-a commitment to centralized responsibility for the prevention of disease, for a healthy environment, the public provision of utilities, and state supervision of salubrity. But Chadwick \& Co. can have their credit without perpetuating the old canard that in the Georgian age London's health deteriorated and nobody cared. The eighteenth century may have lacked a public health movement, worshipping the Chadwickian trinity of legislation, administration and engineering. Yet it certainly possessed a public sickness movement, and an effective one at that. 